\title{
EFEKTIVITAS PETA STRATEGI DALAM ALOKASI BIAYA: SUATU EKSPERIMEN BERBASIS INTERNET
}

\author{
Jesica Handoko )* \\ I Made Narsa $)^{* *}$ \\ Basuki) ${ }^{* *}$ \\ *) Universitas Katolik Widya Mandala Surabaya, Jl. Dinoyo 42-44, Surabaya, Indonesia \\ **) Universitas Airlangga Surabaya, Jl. Airlangga 4-6, Surabaya, Indonesia \\ *jesica@ukwms.ac.id
}

\author{
A R T I C L E I N F O \\ Article history: \\ Received May 21, 2021 \\ Revised July 9, 2021 \\ Accepted September 8, 2021
}

Key words:

Balance Scorecard; Capaian Kinerja;

Outcome Bias; Peta Strategi;

Alokasi Biaya

DOI:

https://doi.org/10.33508/jako.v14i1.3199

\begin{abstract}
A B S T R A C T
Research Purposes. This study aims to test whether there are differences in resource cost allocations when decision makers receive negative or positive information.

Research Methods. This research with a $2 \times 3 \times 2$ mixed subject design was conducted using an internet-based experimental application with the final result of 132 participants who passed the manipulation check.

Research Results and Findings. The study results do not show differences in resource cost allocations when there are differences in performance achievement. The effectiveness of the strategy map is proven to be significant when the decision makers get the strategy map visualization, that is, there is no excessive allocation compared to those in the group without the strategy map visualization.
\end{abstract}

\begin{abstract}
A B S T R A K
Tujuan Penelitian. Penelitian ini bertujuan menguji apakah terdapat perbedaan alokasi biaya sumber daya saat pengambil keputusan mendapat informasi negatif atau positif.

Metode Penelitian. Penelitian dengan desain $2 \times 3 \times 2$ mixed subject ini dilakukan menggunakan aplikasi eksperimen berbasis internet dengan hasil akhir 132 partisipan yang lolos cek manipulasi.

Hasil dan Temuan Penelitian. Hasil penelitian tidak menunjukkan perbedaan alokasi biaya sumber daya saat terdapat perbedaan capaian kinerja. Efektivitas peta strategi terbukti signifikan saat pengambil keputusan mendapat visualisasi peta strategi, yaitu tidak adanya alokasi berlebihan dibandingkan mereka yang ada pada kelompok tanpa visualisasi peta strategi.
\end{abstract}

\section{PENDAHULUAN}

Balanced Scorecard (BSc) superior di dunia bisnis karena dapat digunakan secara interaktif untuk memobilisasi inovasi dan perubahan melalui kepemimpinan eksekutif, menterjemahkan dan menyelaraskan berbagai inovasi pada strategi, serta mampu mengatur agar inovasi menjadi proses yang berkelanjutan (Kaplan, 2009; Chenhall dan Moers, 2015). Pernyataan ini didukung hasil survei Bain dan Company yang pada tahun 2018 menunjukkan bahwa tingkat kepuasan dalam penggunaan BSc masih bertahan diskala 3,93 (Rigby dan Bilodeau, 2018).

Meskipun BSc populer dalam waktu yang cukup panjang, akan tetapi Hoque (2014) juga menggarisbawahi sedikitnya topik penelitian tentang efek hubungan kausal BSc seperti konsep tentang peta strategi. Peta strategi dari tiap tujuan strategis perusahaan dibutuhkan untuk semua proyek, yang kemudian diturunkan pada pemilihan berbagai matrik ukuran-ukuran kinerja BSc (Kaplan, 2009). Kaplan dan Norton (2006) menegaskan bahwa BSc dan peta strategi memperjelas prioritas perusahaan dan mengkomunikasikan prioritas tersebut dari pihak korporat pada semua unit bisnis maupun pendukung dibawahnya. Meskipun merupakan komponen BSc yang penting, penelitian tentang kemanfaatan peta strategi masih dipandang perlu karena model kausal ini belum banyak digunakan oleh organisasi, dan peta strategi pada BSc membutuhkan biaya pengembangan, validasi dan kuantifikasi yang cukup besar (Farrell, Kadous dan Towry, 2012). 
Penelitian ini adalah penelitian eksperimen yang membuktikan pentingnya peta strategi dalam implementasi BSc. Eksperimen awal tentang kemanfaatan peta strategi dilakukan oleh Banker, Chang dan Pizzini (2004) untuk mengatasi bias ukuran-ukuran umum BSc. Banker, Chang dan Pizzini (2004) menyatakan bahwa saat ukuranukuran yang terkait dan tidak terkait strategi dirangkum dalam suatu visualisasi peta strategi, maka penilai akan dapat memanfaatkan ukuranukuran unik untuk mengetahui keefektifan strategi unit bisnis. Penelitian Banker, Chang dan Pizzini (2004) kemudian disederhanakan oleh Humphrey dan Trotman (2011) dengan desain eksperimen yang menghubungkan seluruh ukuran kinerja (baik ukuran umum maupun ukuran unik) dengan strategi serta menyajikan informasi strategis yang lebih detil pada partisipan eksperimen. Hasil penelitian Humphrey dan Trotman (2011) menunjukkan ketiadaan bias ukuran umum yang konsisten dengan temuan Banker, Chang dan Pizzini (2004).

Kemanfaatan peta strategi juga dieksperimenkan oleh Capelo dan Dias (2009), Cheng dan Humphreys (2012), Johnson, Reckers dan Bartlett (2014), Kaplan, Petersen dan Samuels (2012), maupun Humphreys, Gary, dan Trotman (2016). Kaplan, Petersen dan Samuels (2012) melanjutkan penelitian Banker, Chang dan Pizzini (2004) dengan skema adanya bias efek negatif dalam skenario eksperimennya. Temuan Kaplan, Petersen dan Samuels (2012) mendukung dugaan adanya bias efek negatif. Selain membantu memetakan ukuran-ukuran kinerja strategis untuk membantu evaluasi kinerja oleh evaluator baik yang belum mempertimbangkan dimensi waktu (Banker, Chang dan Pizzini, 2004) maupun yang telah mempertimbangkan dimensi waktu (Johnson, Reckers dan Bartlett, 2014; Bartlett, Johnson dan Reckers, 2014), peta strategi BSc juga bermanfaat mengurangi bias dan konflik (Handoko dan Wehartaty, 2017) maupun mengintepretasikan relevansi strategis dari informasi eksternal serta menilai implikasinya pada ketepatan strategi organisasi (Cheng dan Humphreys, 2012).

Penelitian ini menduga peta strategi akan mempengaruhi rencana anggaran, yaitu terkait alokasi biaya sumber daya. Rencana alokasi biaya yang tepat diduga akan mampu meningkatkan kinerja pada periode mendatang. Kaplan (2009) menyatakan bahwa salah satu dari 6 tahapan dalam sistem manajemen komprehensif adalah menghubungkan rencana strategis dengan eksekusi proses operasional, yang salah satu bentuknya adalah proses penganggaran atau alokasi biaya sumber daya. Efektivitas peta strategi boleh jadi terjadi saat peta strategi mampu mengurangi disalignment alokasi biaya sumber daya, yang timbul dari alokasi berlebihan tanpa mempertimbangkan efek jangka panjang dari implementasi BSc.

Johnson, Reckers dan Bartlett (2014) menyatakan bahwa BSc mendukung kinerja strategis jangka panjang yaitu dengan menekankan pencapaian target ukuran-ukuran kinerja nonkeuangan seperti perbaikan proses, pembelajaran karyawan maupun kepuasan pelanggan. Akan tetapi hasil penelitian terdahulu menunjukkan adanya pengabaian capaian ukuran-ukuran ini (Johnson, Reckers dan Bartlett, 2014). Dengan desain eksperimen yang dikembangkan dari Kaplan, Petersen dan Samuels (2012) yang menduga bahwa terdapat bias negatif saat capaian ukuran-ukuran kinerja di bawah standar, penelitian ini dilakukan dengan motivasi menguji efektivitas peta strategi dalam mendukung implementasi BSc dalam menghasilkan feedback berupa alokasi biaya sumber daya pada periode implementasi berikutnya. Penelitian ini diharapkan dapat mendukung Kaplan dan Norton (2006) yang menyatakan peta strategi dan BSc akan bermanfaat dalam mengkomunikasikan apa yang diinginkan pihak korporat dengan berbagai unit di bawahnya sehingga mampu menciptakan nilai yang diinginkan.

Dari penjelasan di atas rumusan masalah penelitian ini adalah (1) Apakah penyajian peta strategi dan informasinya memengaruhi alokasi biaya sumber daya, dan (2) Apakah saat terdapat kondisi capaian kinerja yang berbeda dengan target, penyajian peta strategi dan informasinya akan memengaruhi alokasi biaya sumber daya? Pada bagian selanjutnya akan dijelaskan kajian literature, pengembangan hipotesis dan metode penelitian eksperimen ini. Bagian hasil pengumpulan data, hasil uji hipotesis dan pembahasan akan dijelaskan pada bagian selanjutnya. Pada bagian akhir berisi kesimpulan, keterbatasan, dan saran penelitian selanjutnya.

\section{KAJIAN LITERATUR DAN PENGEMBANGAN HIPOTESIS}

\section{Kajian Literatur}

Balanced Scorecard

BSc pertama kali diperkenalkan oleh Kaplan dan Norton (1992) sebagai alat ukur kinerja manajemen, yang dapat mengatasi kelemahan dari alat ukur kinerja tradisional berfokus pada ukuran- 
ukuran keuangan saja. Menurut Capelo dan Dias (2009), Kaplan and Norton (1992) memperkenalkan BSc dengan tujuan mengatasi kelemahan sistem pengukuran kinerja tradisional yang berfokus hanya pada ukuran-ukuran keuangan. Pendekatan BSc dikatakan menggabungkan indikator-indikator leading (performance drivers) dan lagging (outcome measures); ukuran-ukuran keuangan dan nonkeuangan serta ukuran-ukuran keras dan lunak yang lebih subyektif.

Chenhall dan Moers (2015) dalam perkembangannya menyatakan bahwa BSc telah berevolusi dari seperangkat ukuran-ukuran keuangan dan keuangan menjadi mekanisme untuk mengembangkan dan mengimplementasikan strategi. Selain itu, BSc akan mengarahkan perhatian pada para pemangku kepentingan (stakeholders) dan tidak hanya pada pemegang saham. BSc juga melepaskan fokus utama pada halhal keuangan, yang umumnya tidak menjadi prioritas dari organisasi nirlaba (Chenhall dan Moers, 2015).

BSc ini menterjemahkan misi dan strategi perusahaan ke dalam tujuan dan ukuran operasional yang dirangkaikan secara terpadu ke dalam empat perspektif yaitu: keuangan, konsumen, proses bisnis internal serta pertumbuhan dan pembelajaran. Menurut Atkinson, Kaplan, Matsumura, dan Young (2012) perusahaan akan mampu melacak hasil kinerja keuangan mereka sekaligus memonitor apakah mereka mampu mencapai pertumbuhan dan profitabilitas mereka di masa mendatang (melalui ukuran-ukuran non-keuangan). Pemilihan dari ukuran-ukuran kinerja dari keempat perspektif di atas perlu diperhatikan, yaitu tentang perlu terdapat kausalitas (cause-and-effect linkages) dari berbagai ukuran-ukuran BSc (Atkinson, dkk., 2012).

Implementasi BSc membawa berbagai kemanfaatan. Kaplan dan Norton (2006) mengelompokkan kemanfaatan yang diperoleh oleh berbagai perusahaan yang menggunakan sistem manajemen kinerja berbasis BSc ke dalam 5 kelompok yaitu: (a) Mobilisasi (mobilization): mengorkestra perubahan melalui kepemimpinan eksekutif; (b) Translasi strategi (strategy translation): mampu mendefinisikan peta strategi, target dan berbagai inisiatif BSc; (c) Keselarasan organisasi (organization alignment): kemampuan menyelaraskan korporat, berbagai unit bisnis, unitunit pendukung, partner eksternal dan para anggota dewan dengan strategi; (d) Motivasi karyawan (employee motivation): yaitu mampu menyediakan pendidikan, komunikasi, penetapan tujuan, kompensasi insentif dan pelatihan spara staf; serta (e) Pengaturan (governance): mengintegrasikan strategi pada perencanaan, penganggaran, pelaporan dan review manajemen. Sebagai sistem manajemen modern, BSc berpotensi melengkapi maupun menggantikan berbagai sistem tradisional, misalnya dalam konteks anggaran, BSc akan lebih mampu mendukung anggaran fleksibel (Khalifeh dan Sivabalan, 2017).

\section{Capaian Kinerja dan Outcome Effect}

Menurut Atkinson, dkk. (2012) suatu sistem pengukuran kinerja dapat digunakan untuk berbagai hal: (a) Mengkomunikasikan tujuantujuan strategis dari perusahaan, (b) Memotivasi karyawan untuk membantu perusahaan mencapai tujuan-tujuan strategis dari perusahaan, (c) Mengevaluasi kinerja dari para manajer, karyawan dan unit-unit operasi, (d) Membantu para manajer untuk mengalokasikan berbagai sumber daya pada kesempatan-kesempatan yang paling produktif dan paling menguntungkan, serta (e) Menyediakan umpan balik untuk mengetahui apakah perusahaan telah mencapai suatu kemajuan dan telah mampu memenuhi ekspektasi para konsumen dan pemegang saham.

Baik laba maupun ukuran-ukuran kinerja keuangan maupun non-keuangan terbukti diboboti secara berbeda oleh para pengambil keputusan saat mereka tidak mendapatkan panduan yang sangat spesifik. Penelitian Wong-On-Wing, Guo, Li dan Yang (2007) menemukan bahwa pada saat terdapat kinerja buruk, manajemen puncak akan menilai lebih rendah capaian manajer-manajer divisinya tanpa mempertimbangkan apakah capaian kinerja tersebut disebabkan oleh formulasi strategi yang buruk atau tidak. Kaplan, Petersen dan Samuels (2012) juga membuktikan bahwa saat terdapat capaian kinerja negatif maka penilaian evaluator cenderung lebih negatif (bias negatif). Kaplan, Petersen dan Samuels (2018) juga mengkonfirmasi relevansi dari efek negatif capaian kinerja.

Lalwani (2006), menyatakan saat pengambil keputusan mendapat informasi negatif dan positif, mereka cenderung memboboti informasi negatif secara berlebihan. Terdapat beberapa teori untuk menjelaskan efek informasi negatif berlebihan ini. Dari sudut pandang teori frequency-weight, misalnya atribut yang negatif dipersepsikan lebih novel daripada atribut positif (Lalwani, 2006). Hal ini disebabkan orang cenderung memandang dunia sebagai tempat yang positif, sehingga adanya cues yang negatif dipersepsikan sebagai sesuatu yang "berbeda" atau "unik" yang kemudian akan 
mendapatkan perhatian tambahan atau rating yang lebih impresif. Outcome effect berupa bias negatif atau bias positif (akibat informasi positif) tidak hanya timbul di bidang pemasaran tetapi juga di bidang akuntansi dan pengendalian manajemen (Wibbeke dan Lachmann, 2020). Diduga informasi ini akan menyebabkan penilaian berlebihan dari evaluator.

Dari penjelasan di atas dapat dikatakan eksperimen yang akan dilakukan dalam penelitian ini merupakan penelitian di bidang akuntansi manajemen keperilakuan. Penelitian jenis ini banyak mengadopsi teori psikologi untuk menjelaskan berbagai praktik akuntansi manajemen karena praktik akuntansi manajemen tidak hanya berdampak pada organisasi dan sosial tetapi juga individu. Ilmu psikologi dianggap tepat untuk menjelaskan pikiran dan perilaku dari individu yang juga merupakan pengguna dari infomasi yang dihasilkan sistem akuntansi manajemen (Birnberg, Luft dan Shields, 2006).

\section{Peta Strategi sebagai Komponen Balanced Scorecard}

Pendekatan BSc menyediakan gambaran tentang masa depan organisasi yang memungkinkan untuk dicapai (visi), jalan menuju kesana (strategi), serta pemetaan tujuan jangka menengah dan jangka pendek yang terkuantifikasi. Strategi mengimplikasikan pergerakan organisasi dari masa kini ke masa depan yang tidak pasti, dan melalui peta strategi, berbagai komponen dari strategi organisasi yang merupakan a big insight bagi para eksekutif dihubungkan. Peta strategi sebagai alat pelengkap BSc, akan mampu mendukung manajer melalui bangunan perspektif sebab-dan-akibat sehingga sistem bisnis mereka dapat dipahami secara lebih baik dan mampu menciptakan nilai (Kaplan dan Norton, 2004).

Kaplan dan Norton (2004) menyimpulkan peta strategi merepresentasikan secara visual berbagai tujuan utama perusahaan dan hubunganhubungan penting diantara mereka yang mampu mendorong terciptanya kinerja perusahaan. Dengan peta strategi, logika dari strategi organisasi dapat terdeskripsikan secara gemerlap (spark) dalam hubungan sebab akibat (Bolt-Lee dan Swain, 2016), yang menunjukkan kejelasan tujuan dalam penciptaan nilai. Dengan adanya peta strategi, pihak manajemen juga dapat mengetahui apakah berbagai ukuran-ukuran kinerja yang digambarkan dalam peta strategi terlalu kompleks atau kurang bermanfaat bagi perusahaan (Hansen dan Schaltegger, 2018).

Penelitian sekarang berfokus pada efektivitas peta strategi dalam alokasi biaya sumber daya. Adanya peta strategi diduga penilaian berlebihan dari pengambil keputusan akan dapat dikendalikan. Adanya causal map dalam sistem pengukuran kinerja strategis menggunakan BSc, peluang terciptanya consensus di antara tim manajemen puncak maupun antar manajer tingkat menengah dibandingkan dengan system pengukuran bukan BSc (Aranda dan Arelano, 2010).

Selain visualisasi peta strategi, narasi atau bingkai untuk menjelaskan peta strategi akan punya efek berbeda. Menurut Birnberg, Luft dan Shields (2006) pembingkaian (framing) dapat dijelaskan dengan teori prospek (prospect theory) pemikiran Kahneman dan Tversky (1979). Teori prospek ini awalnya diperkenalkan untuk mengkritik teori utilitas yang mengasumsikan bahwa individu secara subyektif menilai (mengestimasikan utilitas untuk) tiap kemungkinan keluaran dari keputusan berisiko berdasarkan total kemakmuran atau kesejahteraan dari keluaran tersebut. Berbeda dengan teori utilitas, teori prospek mengasumsikan bahwa individu secara subyektif menilai tiap keluaran sebagai untung atau rugi dengan membandingkan keluaran tersebut pada titik referensi atau status quo (Kahneman dan Tversky, 1979). Prinsip dasar teori prospek adalah bahwa orang memiliki kecenderungan bertindak tidak rasional yaitu lebih enggan mempertaruhkan keuntungan dibandingkan kerugian (Yuniningsih, 2016). Pembingkaian dapat muncul dalam berbagai kondisi, misalnya dalam penelitian Maines dan McDaniel (2000), bingkai timbul dalam bentuk pilihan format pelaporan comprehensive-income dalam laporan keuangan utama. Penelitian sekarang membingkai peta strategi dibedakan menjadi bernarasi positif dan bernarasi negatif.

\section{Pengembangan Hipotesis}

Informasi negatif, dalam konteks penelitian ini, merujuk pada kinerja ukuran-ukuran korporat yang dieksekusi oleh unit bisnis menunjukkan capaian negatif (di bawah target). Diduga saat terdapat kinerja di bawah target, evaluatee akan mengurangi alokasi biaya sumber daya yang berorientasi pada pencapaian leading indicators yang memiliki dimensi waktu pencapaian yang lebih panjang. Bias akibat kinerja negatif ini sejalan dengan teori bias negatif, yaitu adanya informasi negatif akan mendorong judgment yang lebih impresif dari pihak pembuat keputusan, yang dalam kasus eksperimen ini terkait alokasi biaya. 
Kaplan, Petersen dan Samuels (2012) meneliti apakah evaluator saat mengevaluasi kinerja menunjukkan bias negatif yaitu saat capaian kinerja bawahannya di bawah target. Temuan Kaplan, Petersen dan Samuels (2012) maupun Kaplan, Petersen dan Samuels (2018) menyimpulkan adanya bias negatif yaitu saat terdapat kinerja ukuran BSc yang negatif (underperformed) maka penilaian evaluator cenderung lebih negatif. Hasil penelitian Kaplan, Petersen dan Samuels (2012) ini konsisten dengan teori frequency-weight menurut Lalwani (2006) maupun dugaan penilaian berlebihan akibat adanya outcome effect (Wibbeke dan Lachmann, 2020).

Saat capaian kinerja di bawah target, terdapat kecenderungan timbul bias negatif yang menghasilkan pembobotan cues lebih besar atau lebih ekstrem. Sebaliknya, saat terdapat informasi positif terdapat evaluasi yang lebih positif dari seharusnya. Oleh karena itu akan diuji hipotesis berikut:

$\mathrm{H}_{1}$ : Capaian kinerja sebelumnya yang di atas (di bawah) target menyebabkan pengambil keputusan cenderung mengalokasikan biaya sumber daya yang lebih besar (kecil).

Menurut Kaplan dan Norton (2004) peta strategi dalam implementasi BSc bertujuan mendeskripsikan secara visual tentang strategi, yaitu bagaimana mengidentifikasi aset tak berwujud yang memicu peningkatan kinerja pada proses internal organisasi sehingga mampu memberikan nilai bagi konsumen, pemegang saham dan komunitas perusahaan. Peta strategi ini dibutuhkan dalam semua proyek BSc, yang menunjukkan bagaimana tujuan strategis perusahaan diturunkan pada pemilihan berbagai matrik ukuran-ukuran kinerja BSc (Kaplan, 2009). Beberapa penelitian membuktikan bahwa peta strategi BSc sebagai alat bantu untuk mengurangi cognitive load dari evaluator (fiksasi pada ukuran non-strategis (Banker, Chang dan Pizzini, 2004) serta meningkatkan kualitas judgment atas relevansi informasi dan ketepatan strategi (Cheng dan Humphreys, 2012).

Dalam konteks penelitian sekarang peta strategi juga akan bermanfaat bagi pengambil keputusan dalam membuat judgment alokasi biaya sumber daya. Capelo dan Dias (2009) menemukan bahwa peta strategi BSc bermanfaat dalam meningkatkan pembelajaran dan kinerja. Humphreys, Gary dan Trotman (2016) juga sependapat bahwa dalam lingkungan yang dinamis, alokasi biaya sumber daya yang dibantu oleh peta strategi akan menghasilkan laba jangka panjang yang lebih tinggi di samping juga menghasilkan mental model yang lebih baik jika dibandingkan tanpa peta strategi BSc. Dari penjelasan ini terlihat kemanfaatan peta strategi (dibandingkan tidak adanya visualisasi peta strategi). Dari penjelasan di atas akan diuji hipotesis berikut:

$\mathrm{H}_{2}$ : Penyajian peta strategi dan narasi informasinya efektif dalam membantu pengambil keputusan saat mengalokasikan biaya sumber daya.

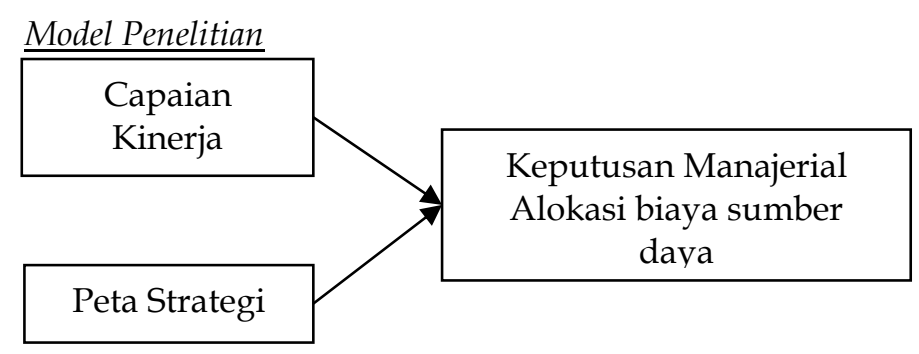

Gambar 1. Model Penelitian

\section{METODE PENELITIAN}

Penelitian ini merupakan penelitian eksperimental yaitu eksperimen laboratorium. Penelitian ini menguji hipotesis yang menjelaskan hubungan kausalitas antar variabel yang diteliti. Variabel yang digunakan dalam penelitian ini adalah capaian kinerja BSc dan informasi peta strategi dalam keputusan alokasi biaya sumber daya.

\section{$\frac{\text { Desain Penelitian }}{\text { Penelitian }}$}

Penelitian ini menggunakan prosedur eksperimen dengan perlakuan terhadap dua belas kondisi eksperimen atau grup perlakuan. Desain eksperimen yang dikembangkan dari Kaplan dan Norton (2006), Kaplan, Petersen dan Samuels (2012) maupun Johnson, Reckers dan Bartlett (2014) ini

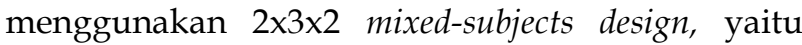
terdapat 2 variabel between subjects dan 1 variabel within-subject. Between-subjects design berarti setiap partisipan yang ada pada satu kelompok akan berpartisipasi pada satu perlakuan yang berbeda dengan kelompok lainnya, yang totalnya sebanyak 6 sel pengamatan. Semua partisipan secara acak (random assignment) dalam satu dari enam sel yang ada. Setiap protokol eksperimen hanya berlangsung pada satu sesi.

Variabel between subjects mencakup Capaian Kinerja dan bingkai Peta Strategi BSc. Capaian kinerja BSc masing-masing memiliki dua level, sedangkan variabel peta strategi memiliki tiga level. Untuk variabel within-subject terdapat 2 level 
yaitu unit bisnis LADYXS di Wilayah Timur dan Wilayah Barat.

Tabel 1. Desain Penelitian Sekarang

\begin{tabular}{|c|c|c|c|}
\hline \multirow{2}{*}{\multicolumn{2}{|c|}{ Peta Strategi }} & \multicolumn{2}{|c|}{ Capaian Kinerja } \\
\hline & & Positif & Negatif \\
\hline \multirow{2}{*}{\multicolumn{2}{|c|}{ Tanpa Peta Strategi }} & $(1)$ & (2) \\
\hline & & Capaian Kinerja Positif, Tanpa Peta & Capaian Kinerja \\
\hline \multirow{2}{*}{ Strategi } & \multirow{3}{*}{ bernarasi } & (3) & (4) \\
\hline $\begin{array}{l}\text { Peta } \\
\text { positif }\end{array}$ & & Capaian Kinerja Positif \& dengan & Capaian Kinerja Negatif \& dengan \\
\hline & & Peta Strategi bernarasi Positif & Peta Strategi bernarasi Positif \\
\hline \multirow{3}{*}{$\begin{array}{l}\text { Peta Strategi } \\
\text { negatif }\end{array}$} & \multirow{3}{*}{ bernarasi } & $(5)$ & (6) \\
\hline & & Capaian Kinerja Positif \& dengan & Capaian Kinerja Negatif \& dengan \\
\hline & & Peta Strategi bernarasi Negatif & Peta Strategi bernarasi Negatif \\
\hline
\end{tabular}

Variabel Penelitian

Ada 2 variabel independen yang dimanipulasi dalam penelitian ini yaitu: (1) Capaian kinerja BSc (CK) dan (2) Informasi peta strategi (PS).

Dua level dari faktor capaian kinerja BSc (CK) yaitu: yaitu (a) capaian kinerja korporat (yang positif atau KP (hasil ukuran-ukuran kinerja korporat pada BSc unit bisnis di atas targetnya) untuk unit bisnis di wilayah Timur dan (b) capaian kinerja korporat yang negatif atau KN (hasil ukuran-ukuran kinerja korporat pada BSc unit bisnis di bawah target) untuk unit bisnis di wilayah Timur. Variabel perlakuan yang pertama ini dikembangkan dari Kaplan dan Norton (2006), Bartlett, Johnson dan Reckers (2014) serta Kaplan, Petersen dan Samuels (2012). Untuk capaian kinerja BSc unit bisnis di wilayah Barat (baik ukuran-ukuran kinerja korporat maupun ukuranukuran unit bisnis pada BSc unit bisnis) seluruhnya di atas target yang sama dengan desain Kaplan, Petersen dan Samuels (2012). Capaian kinerja tahun pertama mencakup kinerja 16 ukuran dari 4 perspektif BSc.

Kaplan, Petersen dan Samuels (2012) membedakan keenam belas ukuran BSc pada eksperimen mereka ke dalam kelompok yang terkait dengan strategi unit bisnis (SBU) dan yang tidak terhubung dengan strategi unit bisnis, masing-masing 2 ukuran pada tiap perspektif BSc. Dalam penelitian sekarang, keenam belas ukuran BSc dikelompokkan berdasarkan ukuran-ukuran yang terhubung dengan strategi korporat (masingmasing 2 ukuran pada tiap perspektif BSc) dan yang terhubung dengan strategi unit bisnis (masing-masing 2 ukuran pada tiap perspektif BSc), berdasarkan Kaplan dan Norton (2006).

Capaian kinerja yang dibedakan menjadi 2 level yaitu capaian kinerja positif atau negatif dilihat dari sudut pandang capaian kinerja ukuranukuran BSc terkait korporat. Capaian kinerja positif (KP) adalah saat ukuran-ukuran kinerja terkait strategi korporat pada BSc unit bisnis LADYXS di Wilayah Timur capaiannya di atas targetnya, dan sebaliknya. Capaian kinerja korporat yang negatif $(\mathrm{KN})$ adalah saat ukuran-ukuran kinerja terkait strategi korporat pada BSc unit bisnis LADYXS di Wilayah Timur capaiannya di bawah targetnya. Capaian kinerja manajer wilayah Barat seluruhnya di atas target.

Tiga level dari faktor bingkai informasi peta strategi (PS) adalah tanpa penyajian visualisasi peta strategi, penyajian peta strategi bernarasi informasi positif serta penyajian peta strategi bernarasi informasi negatif. Penyampaian (narasi) informasi dalam peta strategi juga perlu dipertimbangkan agar memberikan manfaat yang optimal. Hal ini disebabkan bentuk informasi diduga memengaruhi seseorang dalam membuat keputusan yang berisiko (Yuniningsih, 2016). Bentuk informasi ini dapat bersifat positif atau negatif, menyenangkan atau tidak menyenangkan, untung atau rugi. Narasi informasi yang negatif cenderung berdampak lebih luas terhadap psikologi seseorang dibandingkan narasi positif.

Tiga level dari variabel bingkai informasi peta strategi adalah tanpa penyajian visualisasi peta strategi (TPS) dengan narasi netral, menyajikan peta strategi bernarasi informasi positif (PSIP) serta menyajikan peta strategi bernarasi informasi negatif (PSIN). Berikut visualisasi peta strategi pada eksperimen ini. 


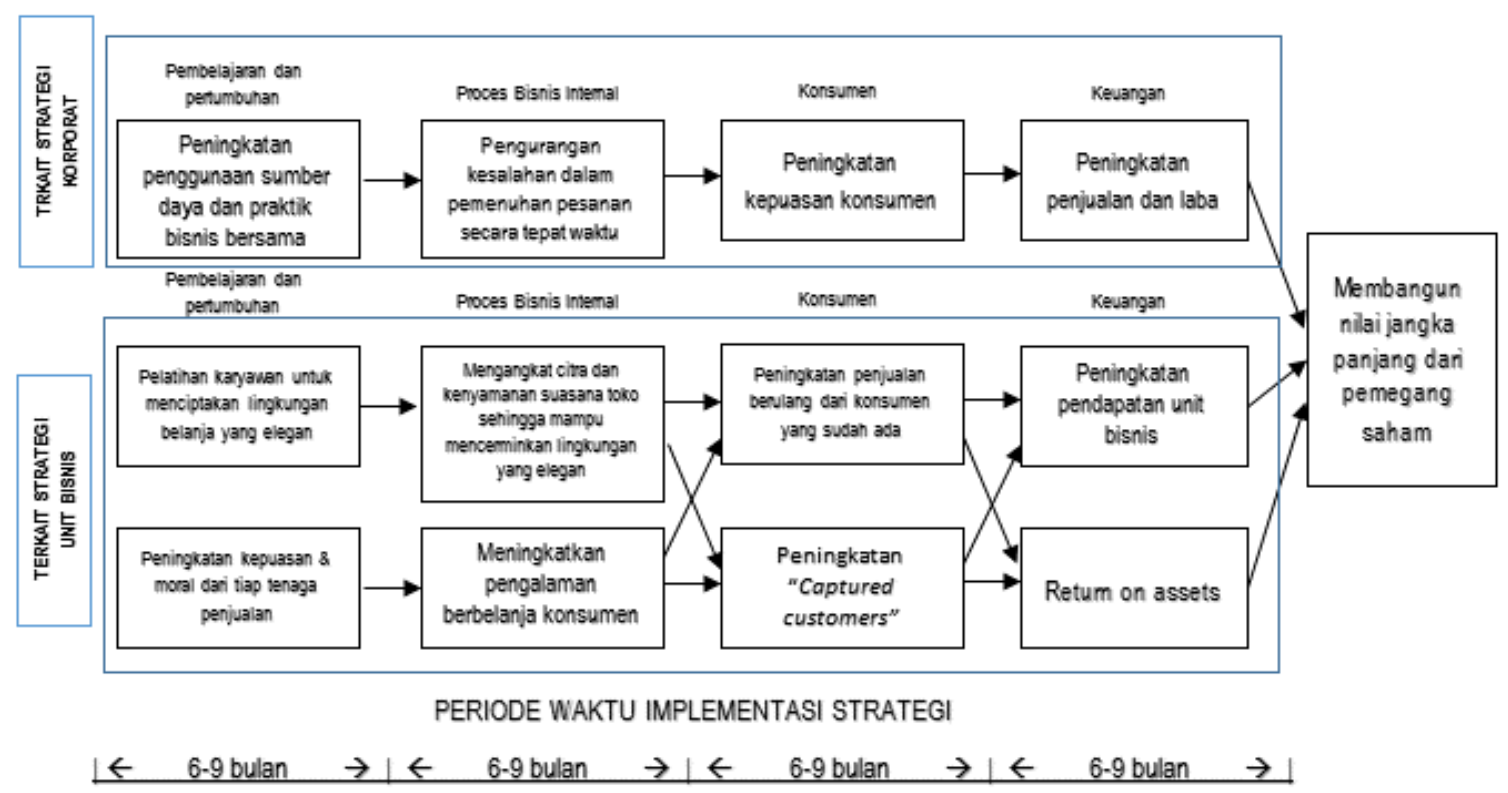

GAMBAR 2. VISUALISASI PETA STRATEGI EKSPERIMEN

Variabel dependen yang akan diukur yaitu: me-review alokasi anggaran biaya operasional tahun berikutnya senilai total Rp100.000.000.000,(seratus milyar rupiah) untuk bagi kedua manajer wilayah, yaitu manajer wilayah timur (Mawar Pertiwi atau MT) dan wilayah barat (Teguh Perkasa atau MB). Pada tahun sebelumnya, sebelum diketahui capaian kinerja kedua manajer wilayah, diinformasikan bahwa jumlah dana operasional yang dialokasikan bagi kedua manajer wilayah adalah sama banyak. Pengisian alokasi biaya ini dalam bentuk persentase biaya yang dialokasikan bagi manajer wilayah timur (dan sisanya otomatis bagi manajer wilayah barat), untuk tiap kegiatan perspektif BSc. Jadi, isian dari tiap peserta akan mencakup alokasi untuk perspektif keuangan (KEU-MT dan KEU-MB), perspektif konsumen (KSMT dan KS-MB), perspektif proses bisnis internal (PIB-MT dan PIB-MB), dan perspektif pembelajaran dan pertumbuhan (PP-MT dan PP-MB).

Tugas alokasi biaya sumber daya juga telah dilakukan Capelo dan Dias (2009) maupun Humphreys, Gary, dan Trotman (2016) dengan simulator, akan tetapi dalam penelitian ini menggunakan google forms untuk menjangkau lebih banyak partisipan sesuai dengan syarat minimal jumlah partisipan menurut Nahartyo dan Utami (2019:110). Selain tugas mengisi nilai variabel dependen, tiap partisipan juga melengkapi berbagai pertanyaan terkait cek manipulasi, demografi maupun pertanyaan penutup lainnya.

Sebelum eksperimen dilakukan pada partisipan yang sesungguhnya, terlebih dahulu dilakukan pilot test (pretest). Tujuannya untuk mengetahui apakah kasus yang diberikan dapat dipahami atau tidak oleh partisipan, apakah terdapat ketidakjelasan informasi dan instruksi pelaksanaan serta ketidakefisienan dalam alokasi waktu pelaksanaan. Selain itu peneliti dapat mengetahui kesalahan dalam desain dan memantau apakah perlakuan telah disampaikan dengan tepat (Cooper dan Schindler, 2014).

Penelitian eksperimen yang dilakukan dapat dikatakan telah mempertimbangkan penanganan terhadap ancaman validitas eksternal seperti yang dijabarkan oleh Narhartyo dan Utami (2019), yang mencakup:

1. Adanya protokol eksperimen yang sama bagi tiap calon partisipan untuk menghindari ancaman histori, yaitu kejadian ekstrani atau kejadian historis yang bukan disebabkan oleh manipulasi eksperimen. Protokol ini dilakukan secara online dengan google forms software.

2. Permintaan persetujuan dari tiap calon responden untuk kesediaan mengikuti prosedur eksperimen sekitar +/- 30 menit yang telah dijelaskan pada saat awal yaitu saat ajakan untuk mengikuti eksperimen. Tujuan pemberitahuan waktu pengerjaan ini untuk mengurangi efek maturasi dari calon partisipan maupun ancaman mortalitas karena diharapkan saat mengetahui durasi waktu penelitian. 
3. Pembatasan waktu pengambilan data eskperimen yaitu maksimal 2 bulan untuk menghindarkan ancaman testing, yang dapat timbul karena pengalaman subyek yang terbiasa atas materi eksperimen.

4. Penugasan secara random (random assignment) untuk setiap partisipan adalah teknik yang dilakukan peneliti untuk mengurangi ancaman validitas internal.

\section{Partisipan Penelitian}

Sampel adalah minimal mahasiswa S-2 Program Magister Manajemen atau Magister Akuntansi Fakultas Ekonomi dan Bisnis dari Universitas di Surabaya dan sekitarnya, yang telah mengambil dan lulus mata kuliah Akuntansi Manajemen atau Manajemen Strategik. Alasan penggunaan partisipan ini yang akan diproksikan sebagai pihak manajemen adalah: (1) calon partisipan telah memiliki dasar-dasar pengambilan keputusan yang cukup memadai serta (2) calon partisipan telah mendapatkan pengetahuan (memiliki bekal akademik) tentang balanced scorecard.

Selain pertimbangan bekal akademik, menurut Nahartyo dan Utami (2019) penggunaan mahasiswa juga masih dianggap tepat apabila peneliti hanya ingin meneliti proses kognitif manusia dalam memproses informasi dan membuat keputusan umum. Sampel dapat juga mereka yang telah lulus Program Magister Manajemen atau Magister Akuntansi atau bahkan mahasiswa Doktoral Program Pascasarjana dari Fakultas Ekonomi dan atau Bisnis. Khalifeh dan Sivabalan (2017) juga menggunakan sampel mahasiswa yang tingkatannya lebih tinggi dari mahasiswa S2 dengan pertimbangan karena calon partisipan ini sebagian besar telah memiliki pengalaman kerja sekaligus memiliki dasar pengetahuan yang kuat. Minimal jenis sampel ini dikatakan telah dilatih untuk berpikir seperti manajer di masa depan (Khalifeh dan Sivabalan, 2017).

Karena ketiadaan kelas offline dalam masa pandemi Covid-19 di Indonesia sejak Maret 2020, maka pengambilan data akan dilakukan secara online, yaitu calon partisipan adalah mereka yang memenuhi persyaratan akademik dan akan berpartisipasi secara online dengan software google forms. Treatmen atau perlakuan dibedakan pada scenario. Telah disiapkan 6 paket google form yang berisi scenario yang berbeda sesuai dengan yang dijelaskan pada desain penelitian. Pengiriman scenario dikirimkan secara acak pada tiap calon partisipan yang bersedia mengikuti eksperimen (randomly assigned).

Meskipun bukan merupakan in-lab ataupun face-to-face experiment, pengiriman instrumen secara on-line mempunyai beberapa keunggulan (Brandon, Long, Loraas, Mueller-Phillips dan Vansant, 2014) yaitu memungkinkan: (a) peneliti untuk menugaskan para partisipan secara random ke dalam sel-sel penelitian, (b) pengiriman link materi penelitian dikirimkan melalui email, website, maupun lewat media social, (c) makin singkatnya kecepatan data untuk dikumpulkan dan di-coding dalam berbagai format yang siap diolah dan dianalisis, serta (d) dapat menjangkau populasi yang sulit. Berbagai keunggulan pengiriman instrumen secara on-line ini akan mengurangi sentralisasi partisipan, mengurangi biaya dan waktu penelitian serta meningkatkan validitas eksternal dari partisipan yang seringkali menjadi kelemahan dari penelitian eksperimen laboratorium (Brandon, dkk, 2014).

\section{Pengujian Hipotesis Penelitian}

Data dari partisipan atau subyek untuk menguji hipotesis penelitian akan diolah menggunakan repeated measure analysis of variance (Repeated ANOVA) dengan tingkat signifikansi penolakan hipotesis nol sebesar 5\%. Penggunaan alat statistis ini dilakukan karena adanya variabel within-subject, seperti yang disarankan oleh Huck (2012) maupun Ghozali (2018).

Dalam pengujian analysis of variance terdapat beberapa uji asumsi yang dilakukan mencakup (Ghozali, 2018):

a. Randomisasi

Untuk tujuan uji signifikansi, maka subyek dalam setiap grup atau cell perlakuan harus diambil secara random. Dalam penelitian ini penugasan telah dilakukan secara acak (random assignment).

b. Uji homogenitas variansi

Uji homogenitas variansi bertujuan mengetahui apakah terdapat varian yang sama dalam tiap kategori variabel independen. Uji homogenitas variansi menggunakan Lavene's test of equality of error variances, dengan batas tingkat signifikansi 0,05. Kriteria penilaian terjadinya homogenitas variansi adalah saat nilai $p$-value hasil Lavene's test di atas 0,05.

c. Sphericity assumption dengan Mauchley-test Untuk mendapatkan nilai F-test yang valid saat menggunakan repeated measures analysis of variance (ANOVA), setiap peneliti perlu mempertimbangkan asumsi kebulatan atau 
sphericity assumption (Huck, 2012). Apabila aplikasi dari Mauchley-test menghasilkan hasil yang signifikan secara statistis maka dikatakan tidak terjadi kondisi sphericity

Hasil uji Repeated ANOVA ini digunakan untuk menentukan apakah terdapat perbedaan antar grup-grup perlakuan dalam penelitian. Hasil uji Repeated ANOVA ini digunakan untuk menentukan apakah terdapat perbedaan antar grup-grup perlakuan dalam penelitian. Untuk efek utama dari variabel capaian kinerja $\left(\mathrm{H}_{1}\right)$ maupun peta strategi $\left(\mathrm{H}_{2}\right)$ akan dilihat dari nilai uji $\mathrm{F}$ dengan tingkat signifikansi $5 \%$ atau $10 \%$. Nilai uji $F$ juga dapat diketahui dari efek interaksi kedua variabel.

\section{HASIL DAN PEMBAHASAN}

\section{Hasil Penelitian}

Hasil Pengumpulan Data

Secara keseluruhan penelitian dilakukan secara online dengan bantuan aplikasi whatsapp, whatsapp autotext dan google forms. Periode pengumpulan data adalah pada bulan Juli sampai dengan Agustus 2020, dengan menyebarkan undangan untuk berpartisipasi dalam eksperimen kepada grup mahasiswa Program Magister Manajemen atau Magister Akuntansi atau bahkan mahasiswa Doktoral Program Pascasarjana dari Fakultas Ekonomi dan atau Bisnis di Surabaya dan sekitarnya. Penelitian ini berupaya membatasi bias waktu dengan membatasi pengambilan sampel selama 2 bulan serta menginformasikan bahwa keikutsertaan dalam eksperimen kurang lebih 30 menit dan memberikan keleluasaan bagi partisipan untuk memutuskan apakah akan ikut serta dalam eksperimen atau tidak.

Selama periode pengumpulan data terdapat 564 bitlinks kesediaan berpartisipasi dari calon partisipan yang direspon melalui aplikasi whatsapp, dan 410 bitlinks materi google form eksperimen yang terakses (ditindaklanjuti oleh calon partisipan). Pada akhirnya jumlah materi eksperimen yang kembali dan diisi lengkap adalah sebanyak 148 formulir (36,1\%).

Sampel akhir yang lolos cek manipulasi adalah 132 (seratus tiga puluh dua) orang partisipan yang minimal adalah mahasiswa S-2 atau S-3 Jurusan Akuntansi atau Manajemen atau 89,19 persen dari jumlah sampel awal. Secara keseluruhan, terdapat 77 orang wanita dan 55 orang pria yang berpartisipasi dalam eksperimen ini. Enam puluh dua orang merupakan mahasiswa Magister Akuntansi atau Magister Manajemen (47\%), 56 orang telah lulus Program Magister S-2 dan sisanya telah lulus Program Doktoral Jurusan Akuntansi atau Manajemen. Mean (deviasi standar) untuk umur dan pengalaman kerja subyek berturut-turut 33,56 (10,29) dan 7,99 $(9,24)$ tahun. Dari jumlah tersebut, sebagian besar sampel bidang studi atau pekerjaannya terkait Akuntansi, Audit atau Perpajakan (62 orang atau 47\%), sedangkan yang lain tersebar di bidang Keuangan, Manajemen Strategik atau bilang lainnya.

Data demografi subyek berupa jenis kelamin, status pendidikan, umur, dan pengalaman kerja dianalisis lebih lanjut untuk mengetahui normalitas distribusi subyek untuk tiap sel. Hasil Chi-square test of independence untuk jenis kelamin (JK) dan status pendidikan (EDUC) menunjukkan tingkat signifikansi di atas 0,05. Hasil tes KolmogorovSmirnov untuk umur (AGE) dan pengalaman kerja (AGE) hanya sebagian yang menunjukkan tingkat signifikansi di bawah 0,05, yang diduga disebabkan oleh berbedanya status pendidikan partisipan. Uji analysis of variance yang dilakukan pada variabel demografi jenis kelamin, status pendidikan (EDUC), serta bidang minat/kerja (FIELD) sebagai kovariat tidak menunjukkan pengaruh signifikan (p-value $>0,05)$.

\section{Hasil Pengujian Hipotesis}

Sebelum menguji hipotesis, terlebih dahulu dilakukan pengujian homogeneity of variance. Tujuannya adalah mengetahui apakah variabel dependen memiliki varian yang sama dalam setiap kategori variabel independen, yang ditandai dengan nilai lavene test menunjukkan probabilitas di atas 0,05 (Ghozali, 2018). Hasil lavene's test of equality of error variance menunjukkan bahwa hampir seluruh varian sampel sama (probabilitas di atas 0,05). Tabel 2 menunjukkan hasil lavene's test dari kedelapan kelompok biaya yang dianalisis.

Selanjutnya tabel 3 menunjukkan hasil pengujian hipotesis yang menggunakan repeated anova, dengan 2 variabel between-subject capaian kinerja (CK), peta strategi (PS) serta 1 variabel wilayah (MANAJER MT atau MANAJER MB). Hasil pengujian pada Tabel 3 tidak menunjukkan efek utama variabel CK (capaian kinerja) maupun adanya interaksi signifikan untuk variabel Manajer ${ }^{*} \mathrm{CK}$ (dengan $\mathrm{p}<0,05$ atau $\mathrm{p}<0,1$ ). Hal ini menunjukkan bahwa $\mathrm{H}_{1}$ tidak didukung. Capaian kinerja periode sebelumnya baik yang hasilnya di atas target maupun yang capaian kinerja ukuranukuran korporat di bawah target, tidak menyebabkan pengambil keputusan alokasi biaya sumber daya yang berbeda antar manajer wilayah 
secara signifikan.

Pada tabel 4 menjelaskan lebih detil hasil pengujian hipotesis pertama. Pada tabel tersebut sudah sesuai dengan arah penelitian, bahwa saat kinerja ukuran-ukuran korporat yang dieksekusi oleh unit bisnis wilayah Timur (MT) menunjukkan capaian negatif (di bawah target), pengambil keputusan cenderung mengalokasikan persentase biaya yang dianggarkan untuk tahun berikutnya lebih sedikit dibandingkan untuk manajer wilayah Barat (MB) yang seluruh kinerjanya menunjukkan capaian di atas target. Untuk perspektif pembelajaran dan pertumbuhan misalnya manajer MB mendapat alokasi sebanyak 14,7176\% saat kinerja ukuran-ukuran korporat MT di bawah target. Akan tetapi saat kinerja ukuran-ukuran korporat dari manajer MT juga di atas target, manajer MB juga mendapat alokasi biaya sumber daya yang lebih besar daripada MT, yaitu sebesar 15,3\%. Diduga, pengambil keputusan cenderung menyukai capaian kinerja manajer $\mathrm{MB}$ yang secara rata-rata menunjukkan capaian di atas target. Atas capaian ini, manajer MB hamper seluruhnya mendapatkan alokasi biaya yang lebih besar daripada alokasi tahun pertama. Ketidaksignifikanan hasil ini diduga disebabkan berfluktuasinya jawaban responden (standar deviasi yang cukup besar)

Tabel 3 menunjukkan juga menunjukkan hasil pengujian hipotesis kedua, yaitu adanya temuan signifikan dari efek utama variabel PS dan interaksi Manajer*PS (dengan tingkat signifikansi $\mathrm{p}<0,01$ ). Temuan ini menunjukkan $\mathrm{H}_{2}$ didukung. Saat ukuran-ukuran kinerja korporat pada wilayah timur lebih tinggi dari targetnya, partisipan memang merespon sesuai arah yang diharapkan yaitu manajer wilayah timur (MT) mendapat alokasi yang lebih besar dibandingkan manajer wilayah barat (MB), akan tetapi kondisi ini hanya terjadi saat partisipan mendapatkan visualisasi peta strategi.

Pada tabel 5 diketahui bahwa saat partisipan tidak mendapatkan visualisasi peta strategi terdapat alokasi berlebihan bagi manajer wilayah barat (MB) yang semua ukuran-ukuran kinerjanya di atas target, sedangkan saat mereka mendapatkan visualisasi peta strategi, alokasi biaya sumber daya yang dilakukan partisipan tidak berbeda jauh nilainya dari jumlah alokasi periode pertama (seperti yang diskenariokan). Dalam kondisi tanpa peta strategi dan untuk perspektif pembelajaran dan pertumbuhan (PP) misalnya manajer $\mathrm{MB}$ mendapat alokasi sebanyak $23,33 \%$ saat kinerja ukuran-ukuran korporat MT di atas target. Jumlah ini lebih tinggi daripada alokasi bagi manajer MT yang mendapat alokasi $14,952 \%$. Kondisi yang sama juga terjadi saat kinerja MT di bawah target. Dalam kondisi tanpa peta strategi dan untuk perspektif pembelajaran dan pertumbuhan (PP) misalnya manajer MB mendapat alokasi sebanyak $23,352 \%$ yang lebih banyak dibandingkan alokasi untuk manajer MT yang hanya $12,313 \%$. Hasil posthoc menggunakan uji Tukey HSD dan uji Bonferroni menunjukkan perbedaan signifikan antara kelompok tanpa peta strategi dengan kelompok yang mendapat peta strategi, sedangkan untuk peta strategi bernarasi positif dan negatif tidak ditemukan perbedaan signifikan. 
Tabel 2. Hasil Lavene's Test $(\mathbf{n}=132)$

\begin{tabular}{lccccr}
\hline \multicolumn{7}{c}{ Levene's Test of Equality of Error Variances untuk Variabel ALOKASI_KEUa } \\
\hline & $\mathrm{F}$ & df1 & df2 & Sig. & \\
\hline KEU-MT & 0,613 & 5 & 126 & 0,690 \\
\hline KEU-MB & 3,703 & 5 & 126 & 0,004 \\
\hline
\end{tabular}

Tests the null hypothesis that the error variance of the dependent variable is equal across groups.

a. Design: Intercept + ROLE + PS + CK * PS \& Within Subjects Design: MANAGER

Levene's Test of Equality of Error Variances untuk Variabel ALOKASI_KSa

\begin{tabular}{lcrrrrr}
\hline & F & df1 & df2 & Sig. & \\
\hline KS-MT & 1,170 & 5 & 126 & 0,328 \\
\hline KS-MB & 1,166 & 5 & 126 & 0,330 \\
\hline
\end{tabular}

Tests the null hypothesis that the error variance of the dependent variable is equal across groups.

a. Design: Intercept + ROLE + PS + CK * PS \& Within Subjects Design: MANAGER

Levene's Test of Equality of Error Variances untuk Variabel ALOKASI_PIB ${ }^{a}$

\begin{tabular}{lcccccr}
\hline & F & df1 & df2 & Sig. & \\
\hline PIB-MT & 0,721 & 5 & 126 & 0,609 \\
\hline PIB-MB & 2,676 & 5 & 126 & 0,025 \\
\hline
\end{tabular}

Tests the null hypothesis that the error variance of the dependent variable is equal across groups.

a. Design: Intercept + ROLE + PS + CK * PS \& Within Subjects Design: MANAGER

Levene's Test of Equality of Error Variances untuk Variabel ALOKASI_PPa

\begin{tabular}{lcrrrrr}
\hline & F & df1 & df2 & Sig. & \\
\hline PP-MT & 0,269 & 5 & 126 & 0,929 \\
\hline PP-MB & 3,008 & 5 & 126 & 0,013 \\
\hline
\end{tabular}

Tests the null hypothesis that the error variance of the dependent variable is equal across groups.

a. Design: Intercept + ROLE + PS + CK * PS \& Within Subjects Design: MANAGER

Sumber: Data diolah 
Tabel 3. Hasil Eksperimen untuk Alokasi Biaya $(\mathrm{n}=132)$

\begin{tabular}{|c|c|c|c|c|c|}
\hline Variabel & $\mathrm{df}$ & SS & MS & $\mathrm{F}$ & $p$ \\
\hline \multicolumn{6}{|c|}{ 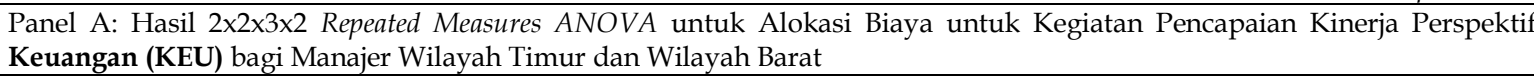 } \\
\hline \multicolumn{6}{|c|}{ Betweeen Subjects: } \\
\hline Intercept & 1 & $48.436,439$ & $48.436,439$ & 643,818 & 0,000 \\
\hline CK & 1 & 37,996 & 37,996 & 0,505 & 0,479 \\
\hline PS & 2 & $2.271,419$ & $1.135,709$ & 15,096 & 0,000 \\
\hline $\mathrm{CK} \times \mathrm{PS}$ & 2 & 59,107 & 29,554 & 0,393 & 0,676 \\
\hline Error & 126 & $9.479,374$ & 75,233 & & \\
\hline \multicolumn{6}{|l|}{ Within Subjects: } \\
\hline Manajer & 1 & $1.471,598$ & $1.471,598$ & 25,848 & 0,000 \\
\hline Manajer x CK & 1 & 14,390 & 14,390 & 0,253 & 0,616 \\
\hline Manajer x PS & 2 & $2.024,555$ & $1.012,277$ & 17,780 & 0,000 \\
\hline Manajer x CK x PS & 2 & 123,206 & 61,603 & 1,0082 & 0,342 \\
\hline Error & 126 & 7173,579 & 56,933 & & \\
\hline
\end{tabular}

Panel B: Hasil 2×2×3×2 Repeated Measures ANOVA untuk Alokasi Biaya untuk Kegiatan Pencapaian Kinerja Perspektif

Konsumen (KS) bagi Manajer Wilayah Timur dan Wilayah Barat

Betweeen Subjects:

\begin{tabular}{|c|c|c|c|c|c|}
\hline Intercept & 1 & $76.764,570$ & $76.764,570$ & 723,058 & 0,000 \\
\hline CK & 1 & 158,976 & 158,976 & 1,497 & 0,223 \\
\hline PS & 2 & $3.587,212$ & $1.793,606$ & 16,894 & 0,000 \\
\hline CK $x$ PS & 2 & 127,893 & 63,946 & 0,602 & 0,549 \\
\hline Error & 126 & $13.376,978$ & 106,166 & & \\
\hline \multicolumn{6}{|l|}{ Within Subjects: } \\
\hline Manajer & 1 & 624,773 & 624,773 & 8,249 & 0,005 \\
\hline Manajer x CK & 1 & 44,899 & 44,899 & 0,593 & 0,443 \\
\hline Manajer x PS & 2 & $2.226,426$ & $1.113,213$ & 14,700 & 0,000 \\
\hline Manajer x CK x PS & 2 & 39,176 & 19,588 & 0,259 & 0,772 \\
\hline Error & 126 & $9.542,008$ & 75,730 & & \\
\hline
\end{tabular}

Panel C: Hasil 2×2×3×2 Repeated Measures ANOVA untuk Alokasi Biaya untuk Kegiatan Pencapaian Kinerja Perspektif

Pencapaian Kinerja Perspektif Proses Bisnis Internal (PIB) bagi Manajer Wilayah Timur dan Wilayah Barat

Betweeen Subjects:

\begin{tabular}{|c|c|c|c|c|c|}
\hline Intercept & 1 & $43.272,190$ & $43.272,190$ & 843,152 & 0,000 \\
\hline CK & 1 & 5,750 & 5,750 & 0,111 & 0,740 \\
\hline PS & 2 & $1.546,102$ & 773,051 & 14,902 & 0,000 \\
\hline CK $\times$ PS & 2 & 80,191 & 40,095 & 0,773 & 0,464 \\
\hline Error & 126 & $6.536,333$ & 51,876 & & \\
\hline \multicolumn{6}{|l|}{ Within Subjects: } \\
\hline Manajer & 1 & 10,923 & 10,923 & 2,716 & 0,102 \\
\hline Manajer x CK & 1 & 0,005 & 0,005 & 0,000 & 0,991 \\
\hline Manajer x PS & 2 & $2,803,414$ & $1.041,707$ & 27,489 & 0,000 \\
\hline Manajer $x$ CK $x$ PS & 2 & 8,479 & 4,240 & 0,112 & 0,894 \\
\hline Error & 126 & $4.774,827$ & 37,895 & & \\
\hline \multicolumn{6}{|c|}{$\begin{array}{l}\text { Panel D: Hasil 2x2×3x2 Repeated Measures ANOVA untuk Alokasi Biaya untuk Kegiatan Pencapaian Kinerja Perspektif } \\
\text { Pencapaian Kinerja Perspektif Pembelajaran \& Pertumbuhan (PP) bagi Manajer Wilayah Timur dan Wilayah Barat }\end{array}$} \\
\hline \multicolumn{6}{|l|}{ Betweeen Subjects: } \\
\hline Intercept & 1 & $55.488,606$ & $55.488,606$ & 666,941 & 0,000 \\
\hline CK & 1 & 4,400 & 4,400 & 0,053 & 0,818 \\
\hline PS & 2 & $2.588,229$ & $1.294,115$ & 15,555 & 0,000 \\
\hline CK $x$ PS & 2 & 6,034 & 3,017 & 0,036 & 0,964 \\
\hline Error & 126 & $10.483,030$ & 83,199 & & \\
\hline \multicolumn{6}{|l|}{ Within Subjects: } \\
\hline Manajer & 1 & 209,845 & 209,845 & 2,992 & 0,086 \\
\hline Manajer x CK & 1 & 63,827 & 63,827 & 0,910 & 0,342 \\
\hline Manajer x PS & 2 & $2.587,031$ & $1.293,516$ & 18,443 & 0,000 \\
\hline Manajer x CK $\times$ PS & 2 & 98,374 & 49,187 & 0,701 & 0,498 \\
\hline Error & 126 & $8.837,212$ & 70,137 & & \\
\hline
\end{tabular}

Sumber: Data Diolah 
Tabel 4. Statistik Deskriptif Variabel Alokasi Biaya Sumber Daya dengan Perbedaan Capaian Kinerja $(n=132)$

\begin{tabular}{|c|c|c|c|}
\hline \multicolumn{4}{|c|}{$\begin{array}{l}\text { Panel A: Persentase Alokasi Biaya bagi Manajer Wilayah Timur (MT) dan Wilayah Barat (MB) saat } \\
\text { Capaian Kinerja Ukuran-Ukuran Korporat Di Atas Target }(n=60)\end{array}$} \\
\hline Peran & & $\begin{array}{l}\text { Mean (std deviasi) bagi Mana- } \\
\text { jer Wilayah Timur (MT) }\end{array}$ & $\begin{array}{l}\text { Mean (std deviasi) bagi Manajer } \\
\text { Wilayah Barat (MB) }\end{array}$ \\
\hline- & $\begin{array}{l}\text { Perspektif } \\
\text { Keuangan (KEU) }\end{array}$ & $10,800 \%(6,449 \%)$ & $16,35 \%(11,849 \%)$ \\
\hline- & $\begin{array}{l}\text { Perspektif } \\
\text { Konsumen (KS) }\end{array}$ & $17,083 \%(9,659 \%)$ & $19,600 \%(11,891 \%)$ \\
\hline- & $\begin{array}{l}\text { Perspektif Proses } \\
\text { Bisnis Internal (PIB) }\end{array}$ & $12,600 \%(6,288 \%)$ & $14,083 \%(9,729 \%)$ \\
\hline & $\begin{array}{l}\text { Perspektif } \\
\text { Pertumbuhan dan } \\
\text { Pembelajaran (PP) }\end{array}$ & $14,300 \%(7,473 \%)$ & $15,300 \%(11,870 \%)$ \\
\hline \multicolumn{4}{|c|}{$\begin{array}{l}\text { Panel B: Persentase Alokasi Biaya bagi Manajer Wilayah Timur dan Wilayah Barat saat Capaian } \\
\text { Kinerja Ukuran-Ukuran Korporat Di Bawah Target }(n=72)\end{array}$} \\
\hline & Peran & $\begin{array}{c}\text { Mean (std deviasi) bagi } \\
\text { Manajer Wilayah Timur (MT) }\end{array}$ & $\begin{array}{l}\text { Mean (std deviasi) bagi Manajer } \\
\text { Wilayah Barat (MB) }\end{array}$ \\
\hline- & $\begin{array}{l}\text { Perspektif } \\
\text { Keuangan (KEU) }\end{array}$ & $12,000 \%(7,352 \%)$ & $15,083 \%(9,645 \%)$ \\
\hline- & $\begin{array}{l}\text { Perspektif } \\
\text { Konsumen (KS) }\end{array}$ & $14,403 \%(7,443 \%)$ & $16,815 \%(12,508 \%)$ \\
\hline- & $\begin{array}{l}\text { Perspektif Proses } \\
\text { Bisnis Internal (PIB) }\end{array}$ & $12,458 \%(7,039 \%)$ & $12,412 \%(7,156 \%)$ \\
\hline- & $\begin{array}{l}\text { Perspektif } \\
\text { Pertumbuhan dan } \\
\text { Pembelajaran (PP) }\end{array}$ & $13,764 \%(7,426 \%)$ & $14,718 \%(11,301 \%)$ \\
\hline
\end{tabular}

Sumber: Data Diolah 
Tabel 5. Statistik Deskriptif Variabel Alokasi Biaya Sumber Daya dengan Perbedaan Peta Strategi $(n=132)$

Panel A: Persentase Alokasi Biaya bagi Manajer Wilayah Timur (MT) dan Wilayah Barat (MB) saat Capaian Kinerja Ukuran-Ukuran Korporat Di Atas Target $(\mathrm{n}=60)$

\begin{tabular}{|c|c|c|c|}
\hline Peran & $\begin{array}{l}\text { Mean bagi Manajer } \\
\text { Wilayah Timur }\end{array}$ & $\begin{array}{l}\text { Mean bagi Manajer } \\
\text { Wilayah Barat }\end{array}$ & $\begin{array}{l}\text { Selisih mean alokasi } \\
\text { biaya }\end{array}$ \\
\hline \multicolumn{4}{|l|}{ Sel Tanpa Petra Strategi $(\mathrm{n}=37)$} \\
\hline - $\quad$ Perspektif Keuangan (KEU) & $10,857 \%$ & $25,476 \%$ & $(14,619 \%)$ \\
\hline Perspektif Konsumen (KS) & $18,143 \%$ & $28,571 \%$ & $(10,428 \%)$ \\
\hline $\begin{array}{l}\text { - } \quad \text { Perspektif Proses Bisnis } \\
\text { Internal (PIB) }\end{array}$ & $12,429 \%$ & $22,619 \%$ & $(10,190 \%)$ \\
\hline $\begin{array}{ll}\text { - } & \text { Perspektif Pertumbuhan dan } \\
& \text { Pembelajaran (PP) }\end{array}$ & $14,952 \%$ & $23,333 \%$ & $(8,381 \%)$ \\
\hline \multicolumn{4}{|c|}{ Sel dengan Petra Strategi bernarasi Positif $(\mathrm{n}=49)$} \\
\hline - $\quad$ Perspektif Keuangan (KEU) & $11,100 \%$ & $12,900 \%$ & $(1,800 \%)$ \\
\hline Perspektif Konsumen (KS) & $16,750 \%$ & $15,850 \%$ & $0,900 \%$ \\
\hline $\begin{array}{l}\text { - Perspektif Proses Bisnis } \\
\text { Internal (PIB) }\end{array}$ & $13,600 \%$ & $10,050 \%$ & $3,550 \%$ \\
\hline $\begin{array}{ll}\text { - } & \text { Perspektif Pertumbuhan dan } \\
& \text { Pembelajaran (PP) }\end{array}$ & $15,200 \%$ & $11,900 \%$ & $3,300 \%$ \\
\hline \multicolumn{4}{|c|}{ Sel dengan Petra Strategi bernarasi Negatif $(\mathrm{n}=46)$} \\
\hline - $\quad$ Perspektif Keuangan (KEU) & $10,421 \%$ & $9,895 \%$ & $0,526 \%$ \\
\hline Perspektif Konsumen (KS) & $16,263 \%$ & $13,632 \%$ & $2,631 \%$ \\
\hline $\begin{array}{ll}\text { - } & \text { Perspektif Proses Bisnis } \\
& \text { Internal (PIB) }\end{array}$ & $11,737 \%$ & $8,895 \%$ & $2,842 \%$ \\
\hline $\begin{array}{ll}\text { - } & \text { Perspektif Pertumbuhan dan } \\
& \text { Pembelajaran (PP) }\end{array}$ & $12,632 \%$ & $10,000 \%$ & $2,632 \%$ \\
\hline \multicolumn{4}{|c|}{$\begin{array}{l}\text { Panel B: Persentase Alokasi Biaya bagi Manajer Wilayah Timur dan Wilayah Barat saat Capaian Kinerja } \\
\text { Ukuran-Ukuran Korporat Di Bawah Target }(n=72)\end{array}$} \\
\hline Peran & $\begin{array}{c}\text { Mean (s.d) bagi } \\
\text { Manajer Wilayah } \\
\text { Timur } \\
\end{array}$ & $\begin{array}{c}\text { Mean (s.d) bagi } \\
\text { Manajer Wilayah } \\
\text { Barat } \\
\end{array}$ & $\begin{array}{l}\text { Selisih mean alokasi } \\
\text { biaya }\end{array}$ \\
\hline \multicolumn{4}{|l|}{ Sel Tanpa Petra Strategi $(\mathrm{n}=37)$} \\
\hline - $\quad$ Perspektif Keuangan (KEU) & $12,438 \%$ & $24,063 \%$ & $(11,625 \%)$ \\
\hline Perspektif Konsumen (KS) & $15,875 \%$ & $29,167 \%$ & $(13,292 \%)$ \\
\hline $\begin{array}{l}\text { - } \quad \text { Perspektif Proses Bisnis } \\
\text { Internal (PIB) }\end{array}$ & $11,250 \%$ & $20,417 \%$ & $(9,167 \%)$ \\
\hline $\begin{array}{ll}\text { - } & \text { Perspektif Pertumbuhan dan } \\
& \text { Pembelajaran (PP) }\end{array}$ & $12,313 \%$ & $26,352 \%$ & $(14,039 \%)$ \\
\hline \multicolumn{4}{|c|}{ Sel dengan Petra Strategi bernarasi Positif $(\mathrm{n}=49)$} \\
\hline - $\quad$ Perspektif Keuangan (KEU) & $12,621 \%$ & $11,621 \%$ & $1,000 \%$ \\
\hline - $\quad$ Perspektif Konsumen (KS) & $13,483 \%$ & $12,103 \%$ & $1,380 \%$ \\
\hline $\begin{array}{ll}- & \text { Perspektif Proses Bisnis } \\
& \text { Internal (PIB) }\end{array}$ & $13,103 \%$ & $9,862 \%$ & $3,241 \%$ \\
\hline $\begin{array}{ll}\text { - } & \text { Perspektif Pertumbuhan dan } \\
& \text { Pembelajaran (PP) }\end{array}$ & $15,621 \%$ & $12,793 \%$ & $2,828 \%$ \\
\hline \multicolumn{4}{|c|}{ Sel dengan Petra Strategi bernarasi Negatif $(\mathrm{n}=46)$} \\
\hline - $\quad$ Perspektif Keuangan (KEU) & $11,074 \%$ & $13,482 \%$ & $(2,408 \%)$ \\
\hline Perspektif Konsumen (KS) & $14,519 \%$ & $14,556 \%$ & $(0,037 \%)$ \\
\hline $\begin{array}{ll}- & \text { Perspektif Proses Bisnis } \\
& \text { Internal (PIB) } \\
\end{array}$ & $12,482 \%$ & $10,407 \%$ & $2,075 \%$ \\
\hline $\begin{array}{ll}\text { - } & \text { Perspektif Pertumbuhan dan } \\
& \text { Pembelajaran (PP) }\end{array}$ & $9,889 \%$ & $9,889 \%$ & $2,741 \%$ \\
\hline
\end{tabular}

Sumber: Data Diolah 
Pembahasan

Hasil penelitian ini tidak menunjukkan dukungan penuh pada dugaan adanya negativity bias sebagai bentuk dari outcome effect menurut Wibbeke dan Lachmann (2020) saat pengambil keputusan melakukan alokasi biaya sumber daya. Saat terdapat capaian kinerja yang berfluktuasi, manajer MT mendapat alokasi biaya sumber daya dengan persentase yang lebih kecil dibandingkan manajer MB. Dengan kata lain temuan penelitian ini tidak konsisten dengan temuan Kaplan, Petersen dan Samuels (2012) maupun Kaplan, Petersen dan Samuels (2018). Akan tetapi, saat partisipan mendapat informasi positif dan tanpa peta strategi, mereka melakukan alokasi biaya sumber daya yang berlebihan (yaitu pada Manajer wilayah Barat yang capaian kinerjanya seluruhnya menunjukkan capaian di atas target.

Bias positif yang ditemukan menunjukkan adanya alokasi biaya berlebihan yang ditunjukkan pada Tabel 5. Peta strategi efektif dalam mengurangi alokasi biaya yang berlebihan pada Manajer Wilayah Barat. Temuan ini memberikan dukungan pada Kaplan dan Norton (2006) yang menekankan pentingnya keselarasan dari manajemen korporat maupun unit-unit dibawahnya saat mereka berbagi sumber daya. Keselarasan dalam alokasi biaya sumber daya (yang dalam hal ini diindikasikan dalam berbagi biaya sumber daya bersama (resource sharing) bagi kedua manajer wilayah) memerlukan peta strategi sebagai komponen penting dari implementasi BSc. Keberadaan peta strategi (terlepas dari narasi informasi yang disajikan) efektif dalam mengurangi disalignment alokasi biaya sumber daya, yayaitu alokasi berlebihan sumber daya bersama tanpa mempertimbangkan efek jangka panjang dari implementasi BSc.

\section{SIMPULAN}

Berdasarkan hasil penelitian yang dijelaskan pada bab sebelumnya, maka diperoleh kesimpulan. Pertama, penelitian ini tidak menemukan bukti empiris bahwa terdapat perbedaan nilai alokasi biaya sumber daya yang signifikan saat partisipan menerima scenario kasus manajerial dengan capaian kinerja ukuran-ukuran korporat di atas atau di bawah target. Kedua, penelitian ini menemukan bukti tentang efektivitas peta strategi sebagai alat bantu keputusan seperti yang diduga oleh peneliti-peneliti sebelumnya, meskipun tidak selalu outcome bias yang timbul pada pengambil keputusan dapat dikurangi. Penelitian ini menemukan bahwa peta strategi cenderung mengarahkan pengambil keputusan untuk tidak melakukan over allocation saat melakukan resource sharing. Temuan dalam penelitian eksperimen ini memberikan beberapa implikasi dalam pengembangan teori dan manfaat kepada pihak luar. Dari sudut pandang teoritis, temuan penelitian mengindikasikan relevansi dari keterbatasan kognitif pengambil keputusan yang menyebabkan timbulnya bias, yang dalam konteks penelitian sekarang yaitu outcome bias. Dalam lingkungan bisnis yang makin dinamis, keputusan penganggaran atau dalam arti sempit yaitu terkait alokasi biaya, perlu dipertimbangkan kemungkinan timbulnya bias ini. Pada akhirnya temuan penelitian ini juga mengimplikasikan pentingnya peta strategi dalam resource sharing Kaplan dan Norton (2006), terutama dalam mencapai keselarasan (alignment) antara korporat dan unit bisnis yang menjadi fokus penelitian ini. Temuan studi ini bermanfaat memberikan dukungan bagi pihak perusahaan yang mengimplementasikan BSc agar secara utuh membangun peta strategi dalam BSc korporat dengan tujuan mencapai keselarasan antar unitunit bisnis, seperti saran Kaplan dan Norton (2006).

Penelitian eksperimen ini mencatat beberapa keterbatasan. Pertama, pengambilan data di luar laboratorium kelas yang direncanakan membuat beberapa kendali internal yang direncanakan tidak terlaksana yaitu pelaksanaan yang tidak serentak pada kelompok-kelompok partisipan. Kedua, latar belakang pendidikan partisipan yang beraneka ragam, tetapi pengalaman kerja terkait BSc yang terbatas. Keempat, kompleksitas desain materi eksperimen yang menyebabkan keterbatasan jumlah partisipan. Terdapat beberapa kemungkinan pengembangan penelitian selanjutnya. Pertama, untuk menghindari tingginya maturation effect dapat dilakukan penyederhanaan desain eksperimen untuk penelitian selanjutnya seperti hanya berfokus pada 1 atau 2 perspektif BSc untuk mengurangi kompleksitas skenario. Kedua, memasukkan variabel lain seperti sistem insentif.

\section{REFERENCES}

Aranda, C. dan Arelano, J. (2010). Consensus and Link Structure in Strategic Performance Measurement Systems: A Field Study, Journal of Management Accounting Research, 22(1), 271299. 
Atkinson, A. A., Kaplan, R. S., Matsumura, E. M. dan Young, S. M. (2012). Management Accounting: Information for Decision Making and Strategy Execution. (edisi ke-6). New JerseyUSA: Pearson Education, Inc.

Banker, R. D., Chang, H. dan Pizzini, M. J. (2004). The Balanced Scorecard: Judgmental Effects of Performance Measures Linked to Strategy. The Accounting Review, 79(1), 1-23.

Bartlett, G., Johnson, E. dan Reckers, P. (2014). Accountability and Role Effects in Balanced Scorecard Performance Evaluations When Strategy Timeline is Specified. European Accounting Review, 23(1), 143-165.

Birnberg, J. G., Luft, J. dan Shields, M. D. (2006). Psychology Theory in Management Accounting Research. Dalam Chapman, C.S., Hopwood, A.G., dan Shields, M.D. (Ed). Handbook of Management Accounting Research (Volume 1, h. 113-135). Oxford: Elsevier

Bolt-Lee, C. E. dan Swain, M. (2016). Highlights of Management Accounting Research, Journal of Accountancy, 222(6), 50-54.

Brandon, D. M., Long, J. H., Loraas, T. M., MuellerPhillips, J. dan Vansant, B. (2014). Online Instrument Delivery and Participant Recruiting Services: Emerging Opportunities for Behavioral Accounting Research. Behavioral Research in Accounting, 26(1), 1-23.

Capelo, C. dan Dias, J.F. (2009). A System Dynamics-based Simulation Experiment for Testing Mental Model and Performance Effects of Using the Balanced Scorecard. System Dynamics Review, 25(1), 1-34.

Cheng, M. M dan Humphreys, K.A. (2012). The Differential Improvement Effects of the Strategy Map and Scorecard Perspectives on Managers' Strategic Judgments. The Accounting Review, 47(3), 1-13.

Chenhall, R.H. dan Moers, F. (2015). The Role of Innovation in the Evolution of Management Accounting and Its Integration into Management Control. Accounting, Organizations and Society, 70, 92-105.

Cooper, D. R. dan Schindler, P. S. (2014). Business Research Methods. (edisi ke-12). Singapore: Mc.Graw Hill.

Farrell, A. M., Kadous, K. dan Towry, K. L. (2012). Does the Communication of Causal Linkages Improve Employee Effort Allocations and Firm Performance? An Experimental Investigation. Journal of Management Accounting Research, 24(1), 77-102.
Ghozali, I. (2018). Aplikasi Analisis Multivariate dengan Program IBM SPSS 25. (edisi ke-9). Semarang: Badan Penerbit Universitas Diponegoro.

Handoko, J. dan Wehartaty, T. (2017). Strategic Balanced Scorecard Implementation in Controlling Bias and Conflict. Polish Journal of Management Studies, 15(1), 57-65.

Hansen, E. G. dan Schaltegger, S. (2018). Sustainability Balanced Scorecards and Their Architectures: Irrelevant or Misunderstood?. Journal of Business Ethics, 150(4), 937-952.

Hoque, Z. (2014). 20 Years of Studies on The Balanced Scorecard: Trends, Accomplishments, Gaps and Opportunities for Future Research. The British Accounting Review, 46(1), 33-59.

Huck, S.W. (2012). Reading Statistics and Research. (Edisi ke-6). Boston: Pearson Education, Inc.

Humphreys, K. A., dan Trotman, K.T. (2011). The Balanced Scorecard: The Effect of Strategy Information on Performance Evaluation Judgments. Journal of Management Accounting Research, 23, 81-98.

Humphreys, K. A., Gary, M. S., dan Trotman, K. T. (2016). Dynamic Decision Making Using the Balanced Scorecard Framework. The Accounting Review, 91(5), 1441-1465.

Johnson, E. N., Reckers, P. M. J. dan Bartlett, G. D. (2014). Influences of Timeline and Perceived Strategy Effectiveness on Balanced Scorecard Performance Evaluation Judgments. Journal of Management Accounting Research, 26(1), 165184.

Kahneman, D. dan Tversky, A. (1979). Prospect Theory: An Analysis of Decision Under Risk. Econometrica, 47(2), 263-292.

Kaplan, R.S. (2009). Conceptual Foundations of the Balanced Scorecard. dalam Chapman, C. S., Hopwood, A. G., dan Shields, M. D. (Ed). Handbook of Management Accounting Research (Volume 3, h. 1253-1269). Oxford: Elsevier.

Kaplan, R.S. dan Norton, D.P. (1992). The Balanced Scorecard-Measures that Drive Performance. Harvard Business Review, January-February 1992, 71-79.

Kaplan, R. S. dan Norton, D. P. (2004). Strategy Maps: Converting Intangible Assets into Tangible Outcomes. Boston: Harvard Business School Publishing Corporation.

Kaplan, R.S. dan Norton, D.P. (2006). Alignment: Using The Balanced Scorecard to Create Corporate Synergies. Boston: Harvard Business School Publishing Corporation. 
Kaplan, S. E., Petersen, M. J. dan Samuels, J. A (2012). An Examination of the Effect of Positive and Negative Performance on the Relative Weighting of Strategically and NonStrategically Linked Balanced Scorecard Measures. Behavioral Research in Accounting, 24(2), 133-151.

Kaplan, S. E., Petersen, M. J. dan Samuels, J. A. (2018). Further Evidence on The Negativity Bias in Performance Evaluation: When Does The Evaluator's Perspective Matter?. Journal of Management Accounting Research, 30(1), 169184.

Khalifeh, C.J.. dan Sivabalan, P. (2017). An Experimental Study on the Effect of Budget Information on Balanced Scorecard Preparer Individual Learning. Australian Accounting Review, 28(64, Issue 1), 39-52.

Lalwani, A.K. (2006). Negativity and Positivity in Product Evaluations: The Impact of Consumer Goals and Prior Attitudes. (Disertasi, Business Administration Program University of Illinois, Urbana-Champaign, Amerika Serikat). Didapat dari https:/ / www.ideals.illinois.edu/handle/2142 /84550.

Maines, L. A., dan McDaniel, L. S. (2000). Effects of Comprehensive-Income Characteristics on Nonprofessional Investors' Judgments: The Role of Financial-Statement Presentation Format. The Accounting Review, 75(2), 179 - 207.

Nahartyo, E., dan Utami, I. (2019). Panduan Praktis Riset Eksperimen. Jakarta: Indeks.

Rigby, D. dan Bilodeau, B. (2018). Management Tools dan Trends: Five Keys Trends Emerged from Bain's Survey of 1.268 Managers. Didapat dari https://www.bain.com/insights/managemen t-tools-and-trends-2017/, 30 Agustus 2020, pukul 22.30 WIB.

Wibbeke, L. M. dan Lachmann, M. (2020). Psychology in Management Accounting and Control Research: An Overview of The Recent Literature. Journal of Management Control, 31(2), 275-328.

Wong-On-Wing, B., Guo, L., Li., W. dan Yang, D. (2007). Reducing Conflict in Balanced Scorecard Evaluations. Accounting, Organizations and Society,32, 363-377.
Yuniningsih. (2016). Keputusan Risk Taking Dalam Berinvestasi Berdasarkan Loss Aversion, Informasi, dan Evaluasi. (Disertasi Program Doktor Ilmu Ekonomi Fakultas Ekonomi dan Bisnis Universitas Airlangga, Surabaya, Indonesia). Didapatkan dari https:/ / repository.unair.ac.id/57295/. 